\title{
DEVELOPMENT A PROTOTYPE FOR IMPROVING THE PERFORMANCE OF THE CLEANING UNIT IN COMBINE HARVESTING MACHINE
}

\author{
Sehsah, E. E. ${ }^{*}$, S. E. Abouzaher ${ }^{* *}$, R.M. Kholief ${ }^{* * *}$ and \\ A.H. El-Hanafy
}

\section{ABSTRACT}

Seed cleaning is an important operation in a number of processes connected with the handling of seed after harvest. The goals of the current research were developing of a laboratory unit for cleaning the wheat crops in combine harvesting machine. The laboratory model was manufactured to simulate and study the aerodynamic characteristics of air and test the performance of the developed cleaning unit at four aerodynamic suction velocities 5.9, 8.5, 11.6 and $14.9 \mathrm{~m} / \mathrm{s}$., three feed rates 3, 5, and $7 \mathrm{~kg} / \mathrm{min}$, two rotational speed 245 and 350 r.p.m to operate the screens, two shapes for suction part rectangular and circle and three slope angles for screens $5^{\circ}, 10^{\circ}$ and $15^{\circ}$ with three replicates. The results indicated that the average of minimum specific energy was $8.46 \mathrm{kw} . \mathrm{h}_{\mathrm{ton}} \mathrm{t}^{-1}$ at $5.9 \mathrm{~m} / \mathrm{s}$ aerodynamic suction velocity, $5^{\circ}$ screen slope, $0.42 \mathrm{ton} / \mathrm{h}$ feed-rate, $245 \mathrm{rpm}$ rotational speed and circle shape of suction tube. Also, the maximum cleanliness was $99.41 \%$ for aerodynamic suction velocity of $14.9 \mathrm{~m} . \mathrm{s}^{-1}$, slope of the screen was $15^{\circ}$, at feed-rate of $3 \mathrm{~kg} . \mathrm{min}^{-1}$, rotational speed of $245 \mathrm{rpm}$ and rectangular shape of suction tube. On the other hand, the minimum grain losses percent was $0.53 \%$ at aerodynamic suction velocity of $5.9 \mathrm{~m} . \mathrm{s}^{-1}$, $5^{\circ}$ slope of the screen, $3 \mathrm{~kg} . \mathrm{min}^{-1}$ feed-rate, $245 \mathrm{rpm}$ rotational speed and circle shape.

Keywords: Aerodynamic properties, development, cleaning unit and combine harvesting

\footnotetext{
*Associate Professor, Agric. Eng. Dept., Faculty of Agric., Kafrelsheikh University, 33516, Egypt.Sehsah_2000@yahoo.de

${ }^{* *}$ Assist. Professor, Agric. Eng. Dept., Faculty of Agric., Kafrelsheikh University

${ }^{* * * *}$ Head researcher, Agric. Eng. Res. Institute. Dokki., Giza. Egypt

***** Engineer, Agric. Eng. Res. Institute. Dokki., Giza. Egypt.
} 


\section{INTRODUCTION}

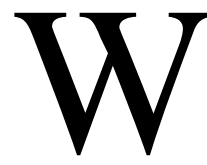

heat is the most important grain crop in Egypt. It represents almost $10 \%$ of the total value of agricultural production and about $20 \%$ of all agricultural imports. Egypt is also the world's biggest wheat importer. wheat production at 2014 was 9.28 million ton and cultivated area was 3.52 million feddan FAO, (2015). Khoshtaghaza and Mehdizadeh (2006) estimated terminal velocity of wheat kernel and straw materials (Canadian variety). They found that by increasing mass of the kernel from 0.02 to $0.05 \mathrm{~g}$ and moisture content from 7 to $20 \%$ (w.b.), its terminal velocity increased from 7.04 to 7.74 $\mathrm{m} / \mathrm{s}$ and 6.81 to $8.63 \mathrm{~m} / \mathrm{s}$, respectively. For air separation of Canadian wheat and straw, the air flow should be less than $7.04 \mathrm{~m} / \mathrm{s}$ and more than $4.85 \mathrm{~m} / \mathrm{s}$. Drag coefficient was 0.96. El-Fawal et al., (2009), El-Sheikha et al., (2010) and Unal et al., (2017) estimated physical properties for wheat variety Giza 9, Giza 168, Sakha 93 and commercial buckwheat at different moisture content. physical properties values for wheat varieties were at range of 6.36-7.46, 3.37-3.942, 2.6-3.210, 21.19-42.669, 3.414.300 and 67.747-89.94 for length $\mathrm{mm}$, width $\mathrm{mm}$, thickness $\mathrm{mm}$, volume $\mathrm{mm}^{3}$, geometric diameter $\mathrm{mm}$ and sphericity $\%$. Angle of repose for wheat varieties were at range of 14.57 and $25.47^{\circ}$. Tabatabaeefar, (2003) concluded that aerodynamic properties separate the stems, leaves, and chaff and light seed. Either a suction fan or blowing fan can be chosen to propel the air. A suction fan will interact with a particle. There are two types of fans, axial and centrifugal. In the axial fan, air flows parallel to the axis. In a centrifugal fan, air enters parallel to the axis but exits perpendicular to the axis, creating a higher pressure more suitable for a sieving machine. Simonyan and Yiljep, (2008) concluded that there was an increase in cleaning loss with increasing screen oscillation frequency ranged between 6 oscillations per seconds and 12 oscillations per seconds. At 6 screen oscillations per second, the cleaning loss is 9.73 $\%$ but at 12 screen oscillations per second, the loss increased to $54 \%$ and generally there was a decrease in cleaning efficiency with increasing sieve oscillation. Grain losses increased with increasing feed rate within the range of $491 \mathrm{~kg} / \mathrm{h}$ and $680 \mathrm{~kg} / \mathrm{h}$. When the feed rate was $491 \mathrm{~kg} / \mathrm{h}$, cleaning loss is $10 \%$ and when feed rate was $680 \mathrm{~kg} / \mathrm{h}$, cleaning loss 
increased to 54\%. Unal, (2009) investigated angle of repose of einkorn and emmer wheat. Angle of repose for einkorn and emmer wheat spikelets were $22.01^{\circ}$ and $23.02^{\circ}$, respectively. Also, $22.31^{\circ}$ and $24.02^{\circ}$ for einkorn and emmer wheat kernels, respectively. Hanna et al., (2010) concluded that increasing the crank speed from $250 \mathrm{rpm}$ to $325 \mathrm{rpm}$ the fennel seed cleanliness decreased in all experiments except that for slope $5.6^{\circ}$. Also, Increasing the screen angle from 5.6 to $8.5^{\circ}$ increases cleanliness. But increasing this angle to $12^{\circ}$ resulted in decreasing cleanliness. Muhammad et al., (2013) concluded that cleaning efficiency decreased with increase in feed rate at the rate of $6.0,3.5$ and $0.8 \%$ per $\mathrm{kg} / \mathrm{s}$ respectively for sorghum, soybean and millet. They attained $100 \%$ cleanliness at feed rates of $13.5,11.5$ and $5.8 \mathrm{~kg} / \mathrm{s}$ respectively. The rates of percentage increase in cleanliness with increase in fan speeds of 0.06, 0.05 and $0.08 \%$ per rpm and attained $100 \%$ cleanliness at fan speeds corresponding to 650,765 and $550 \mathrm{rpm}$ for sorghum, soybean and millet, respectively.

The main aim of the present research is to develop a prototype of the cleaning unit in combine harvesting machine in which the air stream was changed to be dragged upper-wards. As well as, investigating some aerodynamic and mechanical parameters affect the performance of the developed unit and cleaning quality of a mixture of wheat grains, dust and chaff.

\section{MATERIALS AND METHODS}

\section{Hypothesis of the developed cleaning unit}

The separated material from the threshing unit and straw walkers at combine harvester is composed of grain and MOG that consist of chaff, ear fragments (threshed or un threshed)، straw and leaf fragments. This material is fed onto the cleaning shoe by an oscillatory grain pan. On the grain pan, grain pre-segregation may occur due to the following causes: vibratory motion of the grain pan, airflow blown by the fan in the winnowing step between the grain pan and the sieve as shown in Figure 1 Beck, (1999). 


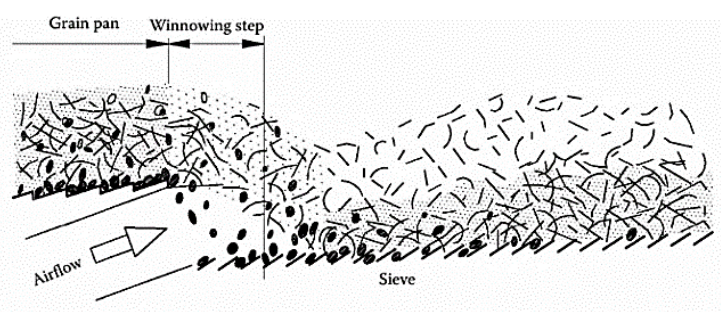

Figure 1: Schematic diagram for cleaning unit at combine harvest.

The hypothesis in the current study is to change the drive airflow to suction airflow as shown in figure 2 . The suction airflow may be able to reduce the MOG and collect it reducing air pollution.

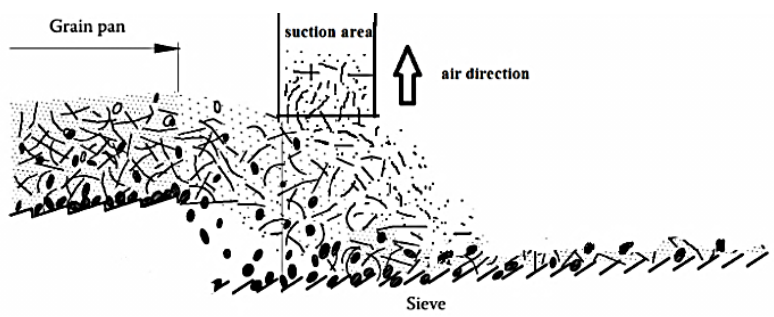

Figure 2: Schematic diagram for the hypothesis of developed cleaning unit.

A laboratory prototype of the cleaning unit in combine harvester was developed, manufactured and fabricated from local materials at the farm machinery laboratory, Agricultural Engineering Department, Faculty of Agriculture, Kafrelsheikh University. It consists of the frame that made of steel. It is supported on the four edges by the L cross-section steel with $67 \mathrm{~cm}$ height from the ground. The screens, power source, feeding hopper, out let gate and control system of screens slope all fixed on the frame. The screening unit consists of two screens (upper and lower) and steel plate with $70 \mathrm{~cm}$ width and $119 \mathrm{~cm}$ length. The upper screen was selected and purchased as a replacement piece of stationary threshing machine having $6 \mathrm{~mm}$ diameter and circular holes. The lower one was selected as a wire screen having $2 \mathrm{~mm}$ longer diagonal of a parallelogram holes. An electric centrifugal blower of $2.2 \mathrm{~kW}(3 \mathrm{hp})$ was used as the source of suction air. The input and output opening diameter of the blower was $8.5 \mathrm{~cm}$, and $15 \mathrm{~cm}$ respectively. An electric single-phase (motor model of Ye3 qiangli) $1.1 \mathrm{~kW}(1.5 \mathrm{hp}$ ) was used as the source of oscillation for screens. A cylindrical collector of plastic for rejected 
material (chaff, dust and grains) with $100 \mathrm{~cm}$ height and $30 \mathrm{~cm}$ diameter was constructed on the outlet of the blower. Balance (type ' $G \& G$ ' made in china) with an accuracy of .01 $\mathrm{g}$ was used for measuring the initial and final weight of wheat samples. Anemometer (Supco DAVM plus digital type) was used for measuring aerodynamic velocity. A digital tachometer (laser HP-2234C) was used to measure the rotational speed of the engine. An electrical digital clamp meter (kyoritsu 2007A AC type) was used to measure ampere and voltage for the blower engine. A watt meter (PSGI) was used to measure electric power consumption for the screening unit. A caliper was used for measuring dimensions of grains. An electric oven was used to determine moisture content of wheat seeds and chaff. The static friction coefficient determined using a digital apparatus fabricated at the Rice Mechanization Center.

\section{Procedure and experiments}

The experiments were carried out under laboratory conditions as the simulator of the cleaning unit in machine harvesting combine. preliminary experiments were conducted to determine terminal velocity for wheat grains variety Gemmiza 11 and to determine one mixture ratio to be as a classification one for all treatments and the appropriate maximum feed rate that the prototype can cope with. However, terminal velocity was found to be $8.5 \pm 0.23 \mathrm{~m} / \mathrm{s}$. Mixture ratio of $30 \%$ representing the MOG (material other than grain) to the total material and $7 \mathrm{~kg} / \mathrm{min}$ as the appropriate feed rate. Then the main experiments were conducted four aerodynamic suction velocities 5.9, 8.5, 11.6 and $14.9 \mathrm{~m} / \mathrm{s}$., three feed rates 3,5 , and $7 \mathrm{~kg} / \mathrm{min}$, two rotational speeds 245 and $350 \mathrm{rpm}$ for the crank to operate the screens, two shapes and the cross-sectional area of the suction part was $56.7 \mathrm{~cm}^{2}$, rectangular $(\mathrm{L}=14.18 \mathrm{~cm}$ and $\mathrm{W}=4 \mathrm{~cm})$ and circle $(r=4.25 \mathrm{~cm})$ and three slope angles for screens 5, 10 and $15^{\circ}$ with three replicates were conducted for each treatment. The feed hopper gate was adjusted to obtain the definite position for feed rate 3, 5 and $7 \mathrm{~kg} / \mathrm{min}$. The slope of the screen also was adjusted at 5,10 and $15^{\circ}$ by screw bolts fixed in the two sides of the screen frame. Two forms of suction tube rectangular and circular were manufactured and changed as trail treatment conditions. 


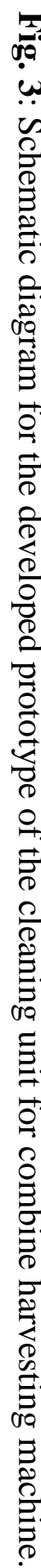
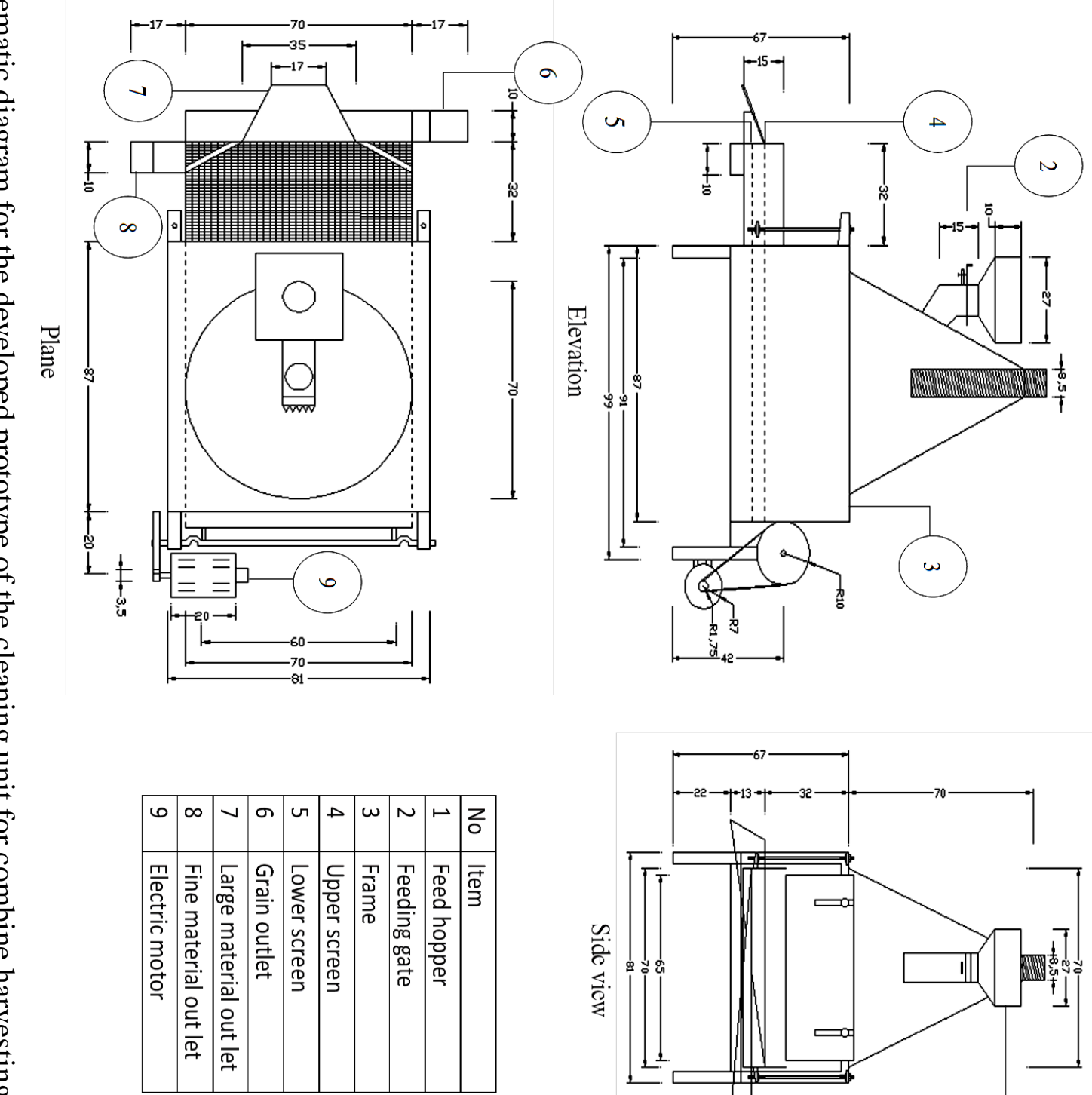

م.

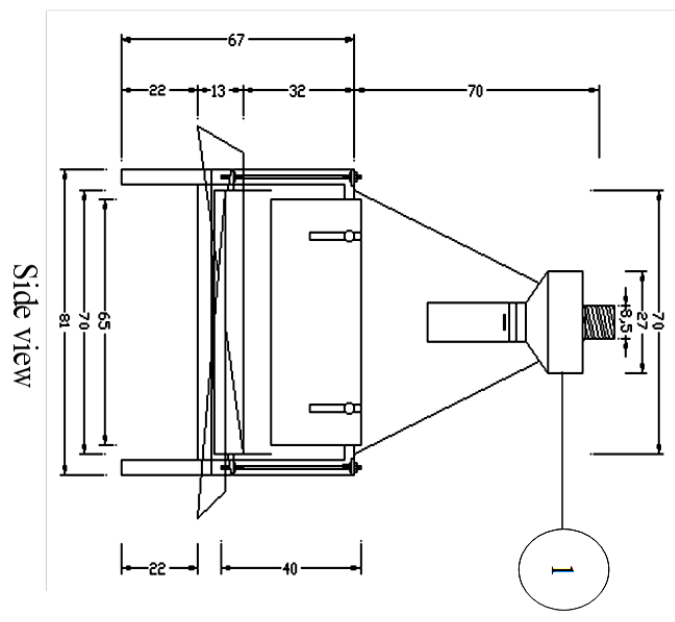

Misr J. Ag. Eng., January 2018 
The terminal velocity was determined by using a digital anemometer. The height of suction tube was set to control the aerodynamic velocity. The rotational speed of 245 and $350 \mathrm{rpm}$ were adjusted by changing the diameter of driver pulley from 3.5 to $5 \mathrm{~cm}$. The operating time of the suction blower and screen was $60 \mathrm{sec}$. The grains and MOG were collected and weighted to calculate the study parameters. The outlet MOG collected after every treatment to calculate the chaff rejected. Also, the power consumption and specific energy was calculated under all treatment conditions.

\section{RESULTS AND DISCUSSION}

\section{Physical, mechanical and aerodynamic properties}

Physical, mechanical and aerodynamic properties for wheat Gemmiza11 variety. were determined according to Mohsenin, (1980) as shown in table 1. The measurements were taken at moisture content of $11.3 \%$ and $9.8 \%$ (d.b) for grain and chaff, respectively for ten replicates.

\section{Power requirement and specific energy}

Power requirement estimated according to Kurt, (1979). Statistical analysis viewed non-significant effect of aerodynamic velocity, screen slope and suction tube shape on power consumption and specific energy. There for, the effect of rotational speed and feed rate on both parameters will be only shown at terminal velocity $(8.5 \mathrm{~m} / \mathrm{s})$, screen slope $5^{\circ}$ and the circular shape of suction tube. The average of power requirement tends to increase with increasing feed-rate and rotational speed under all treatment conditions. Also, the specific energy tends to increase with increasing rotational speed and tends to decrease with increasing feed rate under all treatment conditions. The results indicated that the average of maximum power requirement was $4.03 \mathrm{~kW}$ to clean the average amount of wheat $7 \mathrm{~kg} \cdot \mathrm{min}^{-1}$ at $8.5 \mathrm{~m} / \mathrm{s}$ suction velocity, $5^{\circ}$ screen slope, $350 \mathrm{rpm}$ rotational speed and circular shape of suction tube. On the other hand, the average of minimum power requirement was $3.35 \mathrm{~kW}$ at 8.5 $\mathrm{m} . \mathrm{s}^{-1}$ aerodynamic suction velocity, $5^{\circ}$ screen slope, $7 \mathrm{~kg} \cdot \mathrm{min}^{-1}$ feed-rate, $245 \mathrm{rpm}$ rotational speed and circle shape of suction tube as shown in 
Figure 4. Also, the average of maximum specific energy was 21 $\mathrm{kw} \cdot \mathrm{h} \cdot \mathrm{ton}^{-1}$ at $8.5 \mathrm{~m} . \mathrm{s}^{-1}$ aerodynamic suction velocity, $5^{\mathrm{o}}$ screen slope, 3 $\mathrm{kg} \cdot \mathrm{min}^{-1}$ feed rate, $350 \mathrm{rpm}$ rotational speed and circular shape for suction tube.

Table 1: Physical, mechanical and aerodynamic properties for wheat sample (Gemmiza 11):

Grains physical, mechanical and aerodynamic properties

Value

a) Physical properties:

Length

Width

Thickness

Arithmetic mean diameter

Geometric mean diameter

Sphericity

Volume

Mass thousands of seed

Bulk density

True density

Porosity

Surface area
$7.53 \pm 0.3 \mathrm{~mm}$

$3.23 \pm 0.42 \mathrm{~mm}$

$3.04 \pm 0.26 \mathrm{~mm}$

$4.6 \pm 0.33 \mathrm{~mm}$

$4.197 \pm 0.31 \mathrm{~mm}$

$55.64 \pm 1.03 \%$

$38.71 \pm 0.12 \mathrm{~mm}^{3}$

$51.3 \pm 1.66 \mathrm{~g}$

$856 \pm 7.4$ kg. $\mathrm{m}^{-3}$

$1314.2 \pm 8.45 \mathrm{~kg} . \mathrm{m}^{-3}$

$46.96 \pm 3.9 \%$

$55.43 \pm 0.53 \mathrm{~mm}^{2}$

b) Mechanical properties:

Angle of repose

$25 \pm 1.4^{\circ}$

Angle of static friction

$17.7 \pm 1.88^{\circ}$

Coefficient of static friction

c) Aerodynamic properties:

Grain terminal velocity

$8.5 \pm 0.23 \mathrm{~m} . \mathrm{s}^{-1}$

Chaff terminal velocity

$2.8 \pm 0.13 \mathrm{~m} . \mathrm{s}^{-1}$

Grain drag coefficient

$0.65 \pm 0.03$ 
Also, the average of minimum specific energy was $8.47 \mathrm{kw} \cdot \mathrm{h} \cdot \mathrm{ton}^{-1}$ at 8.5 $\mathrm{m} . \mathrm{s}^{-1}$ aerodynamic suction velocity, $5^{\circ}$ screen slope, $7 \mathrm{~kg} \cdot \mathrm{min}^{-1}, 245 \mathrm{rpm}$ rotational speed and circle shape of suction tube as shown in Figure 4. Figure 4 indicated that increase of rotational speed from 245 to $350 \mathrm{rpm}$ resulted in increasing the average of power requirement from 3.35 to 3.73 $\mathrm{kW}$ at $3 \mathrm{~kg} \cdot \mathrm{min}^{-1}$ feedrate, $5^{\circ}$ screen slope, $8.5 \mathrm{~m} . \mathrm{s}^{-1}$ aerodynamic suction velocity and circle shape of suction tube. Also, presented that the increasing of feed rate from $3 \mathrm{~kg} \cdot \mathrm{min}^{-1}$ to $7 \mathrm{~kg} \cdot \mathrm{min}^{-1}$ tends to increase power requirement from 3.35 to 3.56 at $8.5 \mathrm{~m} . \mathrm{s}^{-1}$ aerodynamic suction velocity, $5^{\circ}$ screen slope, $245 \mathrm{rpm}$ rotational speed and circle shape suction tube.

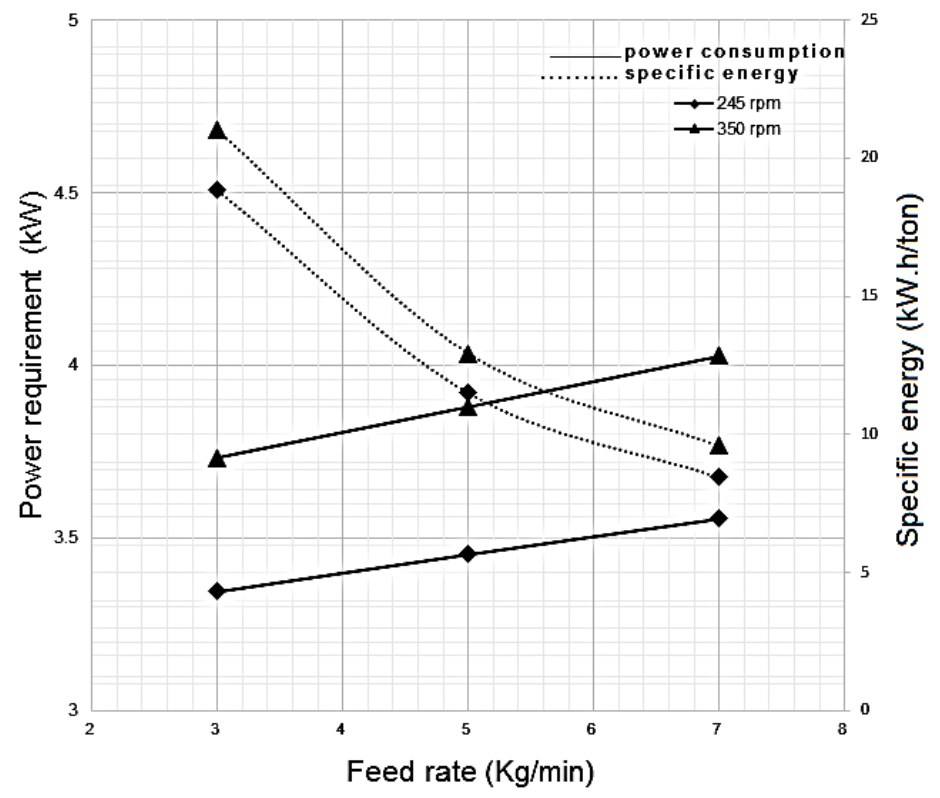

Fig 4: The effect of feed rate and rotational speed on power requirement and specific energy at aerodynamic suction velocity of $8.5 \mathrm{~m} / \mathrm{s}, 5^{\circ}$ screen slope and circular shape of suction tube.

\section{Cleanliness in the prototype of the cleaning unit}

The results indicated that the velocity of suction air, feed rate, slope of screen, rotational speed of screeners effected on the cleanliness of the developed cleaning unit as shown in figure 5. The increasing of suction 
air velocity and slope angle and decreasing of both feed rate and rotational speed tends to increase the percentage of cleanliness. The rectangular shape gave the high values of cleanliness compared to the circular shape of the suction tube. The maximum average of cleanliness was $99.41 \%$ at $14.9 \mathrm{~m} . \mathrm{s}^{-1}$ aerodynamic suction velocity, $15^{\circ}$ screen slope, $3 \mathrm{~kg} \cdot \mathrm{min}^{-1}$ feed rate, $245 \mathrm{rpm}$ of rotational speed and rectangular shape as shown in figure 5. As well as, the minimum average of cleanliness was $94.76 \%$ at $5.9 \mathrm{~m} . \mathrm{s}^{-1}$ aerodynamic suction velocity, $5^{\circ}$ slope of the screen, $7 \mathrm{~kg} / \mathrm{min}$ feed rate, $350 \mathrm{rpm}$ of rotational speed and circle shape as shown in figure 5.

\section{" $245 \mathrm{rpm} "$}

a) Circular

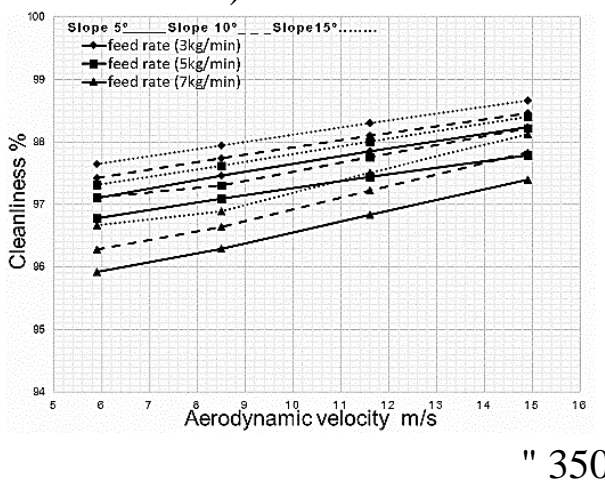

a) Circular

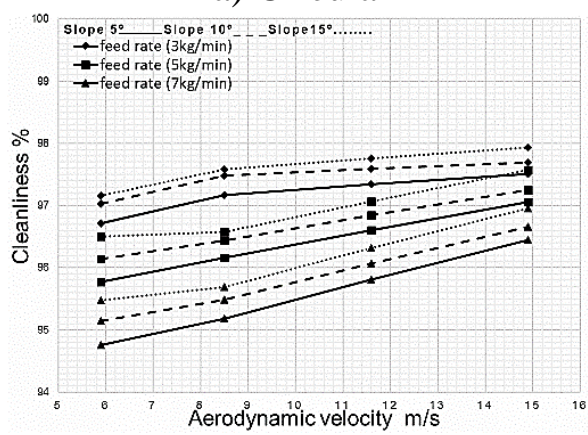

b) Rectangular

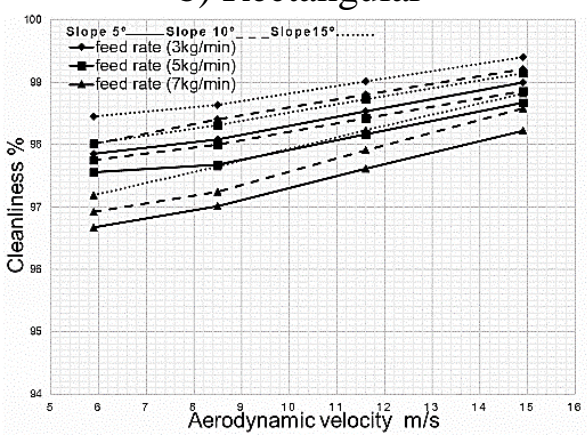

b) Rectangular

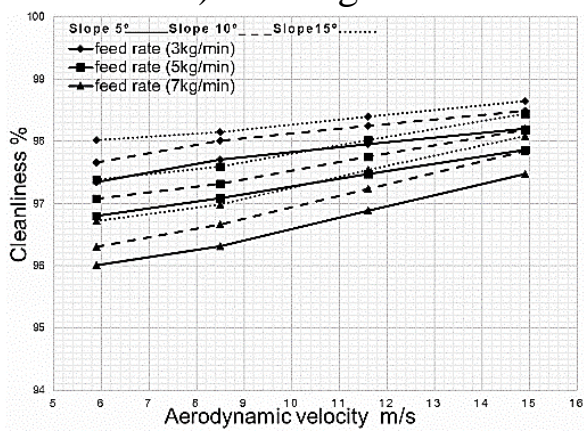

Fig. 5: The effect of aerodynamic suction velocity, feed rate, screen slope, shape of suction tube and rotational speed on cleanliness. 
The average of the cleanliness for $5^{\circ}$ screen slope, $3 \mathrm{~kg} \cdot \mathrm{min}^{-1}$ feed rate, $245 \mathrm{rpm}$ rotational speed and rectangular shape were 97.85, 98.08, 98.82 and $98.24 \%$ for $5.9,8.5,11.6$ and $14.9 \mathrm{~m} . \mathrm{s}^{-1}$ aerodynamic suction velocity, respectively as shown in figure 5 . The above result may be due to the air suction velocity was more than the terminal velocity of straw. Hence, air will be able to lift the straw from the mixture.

The average values of cleanliness were $97.85,98.01$ and $98.45 \%$ for 5 , 10 and $15^{\circ}$ screen slope, respectively at $3 \mathrm{~kg} \cdot \mathrm{min}^{-1}$ feed-rate, $245 \mathrm{rpm}$ rotational speed, $5.9 \mathrm{~m} . \mathrm{s}^{-1}$ for aerodynamic suction velocity and circular shape for suction tube as shown in figure 5. The average values of the cleanliness for treatment conditions of: $5^{\circ}$ screen slope, $5.9 \mathrm{~m} . \mathrm{s}^{-1}$ aerodynamic suction velocity, 245 rotational speed and rectangular shape of suction tube were $97.85,97.56$ and $96.67 \%$ for 3,5 and $7 \mathrm{~kg} \cdot \mathrm{min}^{-1}$ respectively as shown in figure 5 . This result may be due to the increasing of the thickness layer of material (grains and chaff) that collected on the surface of screens which resist grains pass.

\section{Grain losses in prototype of the cleaning unit}

Figure 6 indicated that increasing of aerodynamic suction velocity, slope angle, feed rate and rotational speed tends to increase the average values of grain losses. As well as replacing the shape of suction tube from circle to rectangular increase the average of grain losses.

The maximum average of the grain losses was $4.04 \%$ at $14.9 \mathrm{~m} . \mathrm{s}^{-1}$ aerodynamic suction velocity, $15^{\circ}$ screen slope, $7 \mathrm{~kg} \cdot \mathrm{min}^{-1}$ feed rate, 350 rpm rotational speed and rectangular shape of suction tube as shown in figure 6. On the other hand, the minimum average of grain losses was $0.53 \%$ at $5.9 \mathrm{~m} . \mathrm{s}^{-1}$ aerodynamic suction velocity, $5^{\circ}$ screen slope, 3 $\mathrm{kg} \cdot \mathrm{min}^{-1}$ feed-rate, $245 \mathrm{rpm}$ rotational speed and circle shape of suction tube as shown in figure 6 .

Figure 6 illustrates that average of grain losses for $5^{\circ}$ screen slope, 3 $\mathrm{kg} \cdot \mathrm{min}^{-1}$ feed rate, $350 \mathrm{rpm}$ rotational speed and rectangular shape of suction tube were $1.76 \%, 1.79 \%, 2.23 \%$ and $2.67 \%$ for $5.9,8.5,11.6$ and $14.9 \mathrm{~m} . \mathrm{s}^{-1}$ aerodynamic suction velocity respectively. Also, figure 6 
illustrates that increase of the screen slope from 5,10 to $15^{\circ}$ tends to increase the average values of grain losses from $1.76,2.06$ to $2.48 \%$ at 3 $\mathrm{kg} . \mathrm{min}^{-1}$ feed-rate, $350 \mathrm{rpm}$ rotational speed, $5.9 \mathrm{~m} . \mathrm{s}^{-1}$ aerodynamic suction velocity and rectangular shape of suction tube. Grain losses average values were $1.76,1.82$ and $2.56 \%$ at feed rate of 3,5 and 7 $\mathrm{kg} . \mathrm{min}^{-1}$ for treatment conditions of: $5.9 \mathrm{~m} . \mathrm{s}^{-1}$ aerodynamic suction velocity, $5^{\circ}$ screen slope, $350 \mathrm{rpm}$ rotational speed and rectangular shape of suction tube as shown in figure 6 .

\section{" $245 \mathrm{rpm} "$}

a) Circular

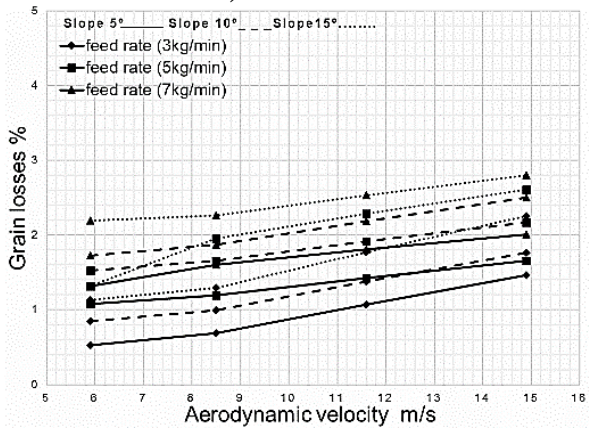

" $350 \mathrm{rpm} "$

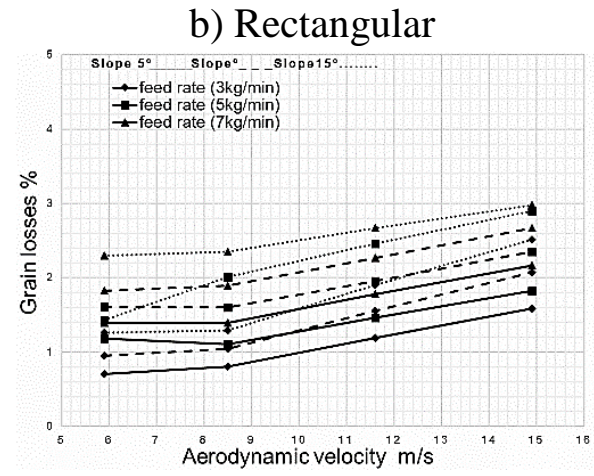

a) Circular

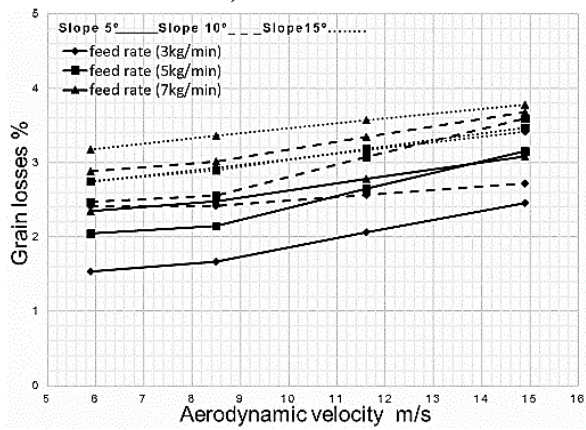

b) Rectangular

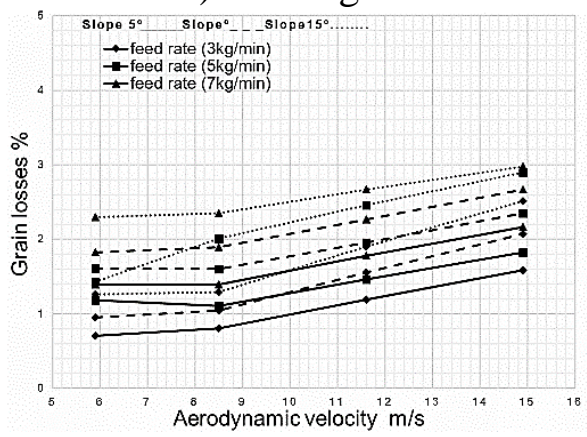

Fig. 6: The effect of aerodynamic suction velocity, feed rate, screen slope, shape of suction tube and rotational speed on grain losses.

The average values of grain losses tended to increase from 0.53 to $1.54 \%$ when the rotational speed increased from 245 to $350 \mathrm{rpm}$ at $3 \mathrm{~kg} \cdot \mathrm{min}^{-1}$ feed rate, $5^{\circ}$ screen slope, $5.9 \mathrm{~m} . \mathrm{s}^{-1}$ aerodynamic suction velocity and circle shape of suction tube as shown in Figures 6. Figure 6 illustrated 
that changing suction tube shape from circle to rectangular resulted in increasing the average of grain losses from 0.53 to $0.71 \%$ at $5.9 \mathrm{~ms}^{-1}$ aerodynamic suction velocity, $3 \mathrm{~kg} \cdot \mathrm{min}^{-1}$ feed-rate, $5^{\circ}$ screen slope and $245 \mathrm{rpm}$ rotational speed.

\section{Chaff rejected in prototype of the cleaning unit}

The results indicated that increasing of the aerodynamic suction velocity and slope angle tend to increase the chaff rejected. On the other hand, decreasing the feed rate and rotational speed tend to increasing chaff rejected. As well as replace the shape of suction tube from circle to rectangular tends to increase the average of chaff rejected.

The maximum average values of the chaff rejected was $98.64 \%$ at 14.9 $\mathrm{m} . \mathrm{s}^{-1}$ aerodynamic suction velocity, $15^{\mathrm{o}}$ screen slope, $3 \mathrm{~kg} \cdot \mathrm{min}^{-1}$ feed-rate, $245 \mathrm{rpm}$ rotational speed and rectangular shape of suction tube as shown in figure 7. Also, the minimum average of the chaff rejected was $88.23 \%$ at $5.9 \mathrm{~m} . \mathrm{s}^{-1}$ aerodynamic suction velocity, $5^{\circ}$ screen slope, $7 \mathrm{~kg} \cdot \mathrm{min}^{-1}$ feed rate, $350 \mathrm{rpm}$ rotational speed and circle shape of suction tube as shown in figure 7.

Figure 7 illustrates that chaff rejected average values were 94.92, 95.47, 96.58 and $97.68 \%$ for $5.9,8.5,11.6$ and $14.9 \mathrm{~m} . \mathrm{s}^{-1}$ aerodynamic suction velocity respectively at the treatment conditions of $5^{\circ}$ screen slope, 3 kg. $\min ^{-1}$ feed-rate, $245 \mathrm{rpm}$ rotational speed and rectangular shape of suction tube.

Figure 7 illustrates that increasing the screen slope from 5,10 to $15^{\circ}$ tends to increase the average of the chaff rejected from 94.92, 95.31 to $96.32 \%$ for $3 \mathrm{~kg} \cdot \mathrm{min}^{-1}$ feed rate, $245 \mathrm{rpm}$ rotational speed, $5.9 \mathrm{~m} . \mathrm{s}^{-1}$ aerodynamic suction velocity and rectangular shape of suction tube. This may be due to the grain, straw and dust moved out of separation unit.

Figure 7 illustrates that the average values of the chaff rejected were $94.92,94.23$ and $92.08 \%$ at feed rate of 3, 5 and $7 \mathrm{~kg} \cdot \mathrm{min}^{-1}$, respectively under treatment conditions of: $5.9 \mathrm{~m} . \mathrm{s}^{-1}$ aerodynamic suction velocity, $5^{\circ}$ screen slope, $245 \mathrm{rpm}$ rotational speed and rectangular shape of suction 
tube. The above result may be due to that increasing the MOG ratio with increasing feed rate and air ability to lift MOG decreases.

The average values of chaff rejected tended to decrease from 90.22 to $88.23 \%$ while the rotational speed increased from 245 to $350 \mathrm{rpm}$ at 5.9 $\mathrm{m} . \mathrm{s}^{-1}$ aerodynamic suction velocity, $7 \mathrm{~kg} . \mathrm{min}^{-1}$ feed rate, $5^{\circ}$ screen slope and circle shape of suction tube as shown in Figures 7.

Figure 7 illustrated that changing suction tube shape from circular to rectangular increased the chaff rejected from 93.08 to $96.08 \%$, respectively at $5.9 \mathrm{~m} . \mathrm{s}^{-1}$ aerodynamic suction velocity, $3 \mathrm{~kg} . \mathrm{min}^{-1}$ feed rate, $5^{\circ}$ screen slope and $245 \mathrm{rpm}$ rotational speed. The above result may be due to the increase of the projected area at rectangular shape than circle, hence air ability to lift chaff increase.

\section{" $245 \mathrm{rpm} "$}

a) Circular

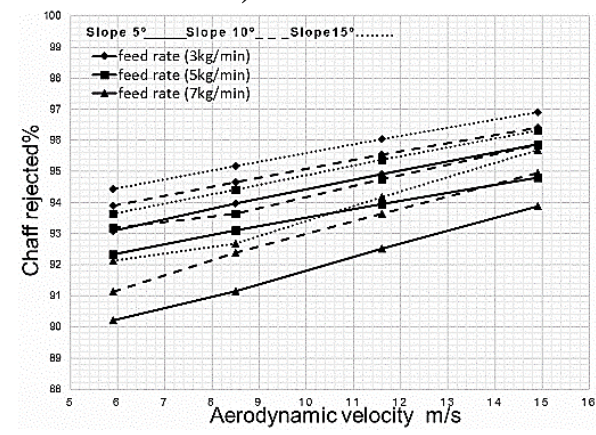

" $350 \mathrm{rpm} "$

a) Circular

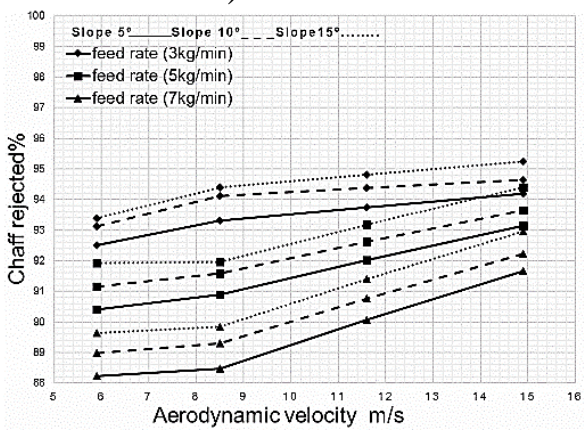

b) Rectangular

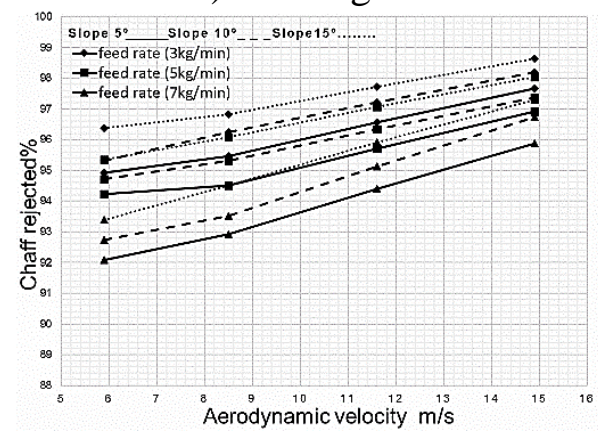

b) Rectangular

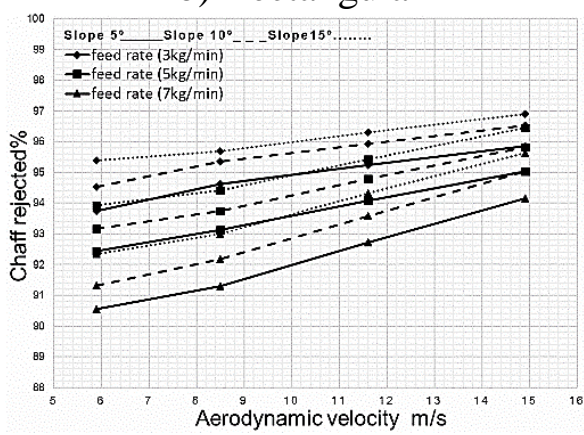

Fig. 7: The effect of aerodynamic suction velocity, feed rate, screen slope, suction tube shape and rotational speed on chaff rejected. 


\section{SUMMARY AND CONCLUSION}

The developed prototype for the cleaning unit of combine harvester was manufactured and development by using the local material as the part of combine harvester.

The average of power requirement trends to increase with increasing feed rate and rotational speed under all treatment conditions. The minimum power requirement was $3.35 \mathrm{~kW}$ at aerodynamic suction velocity of 5.9 $\mathrm{ms}^{-1}$, slope of the screen is $5^{\circ}$, at $3 \mathrm{~kg} \cdot \mathrm{min}^{-1}$ feed rate, rotational speed of $245 \mathrm{rpm}$ and circle shape. The maximum average values for cleanliness was $99.41 \%$ which obtained at aerodynamic suction velocity of 14.9 $\mathrm{m} . \mathrm{s}^{-1}$, screen slope was $15^{\circ}$, for feed rate of $3 \mathrm{~kg} / \mathrm{min}$, rotational speed of $245 \mathrm{rpm}$ and rectangular shape of suction tube.

The maximum average value of the grain losses was $4.04 \%$ for $14.9 \mathrm{~m} . \mathrm{s}^{-1}$ aerodynamic suction velocity, $15^{\circ}$ screen slope, $7 \mathrm{~kg} \cdot \mathrm{min}^{-1}$ feed rate, 350 rpm rotational speed and rectangular shape of suction tube. The maximum average value of the chaff rejected was $98.64 \%$ for $14.9 \mathrm{~m} . \mathrm{s}^{-1}$ aerodynamic suction velocity, $15^{\circ}$ screen slope, $3 \mathrm{~kg} \cdot \mathrm{min}^{-1}$ feed rate, 245 rpm rotational speed and rectangular shape of suction tube.

\section{REFERENCES}

Beck, F. (1999). Simulation of separation processes in combine harvesters. Ph.D. dissertation, Hohenheim University, ForschrittBerichte VDI, Reihe, 14(92).

El-Fawal, Y.A., M.A. Tawfik and A.M. El-Shal. (2009). Study on physical and engineering properties for grains of some field crops. Misr J. Ag. Eng., 26(4), pp: 1933-1951.

El-Sheikha, M.A., H. E. El-Morsy and M. A. I. Al-Rajhi. (2010). Some physical and mechanical properties of Wheat grain. J. of Soil Sciences and Agricultural Engineering. Vol.1 (3), pp: 299 - 309.

FAO. Http://www.fao.org/faostat/en/\#data/QC (5/9/2017) 
Hanna, S., S.M. Ahmed, N.M. El-Ashmawy. (2010). Selection of the main factors affecting cleaning and grading fennel seeds at inclined sieve oscillation. misr j. ag. Eng. 27 (2), pp: $628-643$.

Khoshtaghaza, M. H. and Mehdizadeh, R. (2006). Aerodynamic property of wheat kernel and straw materials. The CIGR E-journal. Vol. (8), Manuscript FP 05007.

Kurt, G. (1979). Engineering formulas. MacGraw hill book company. 3rd ed. New York. St. Louis San Francisco Montreal-Toronto.

Mohsenin, N.N. (1980). Physical properties of plant and animal materials, 2nd ed. Gordon and Breach Science Publishers, New York.

Muhammad, U.S., L.G. Abubakar, M. Isiaka and R.M. Davies. (2013). Design and evaluation of a cleaning machine. App. Sci. Rep. PSCI Publications. Vol. 1 (3), pp: 62-66.

Simonyan, K.J. and Y.D. Yiljep. (2008). Investigating grain separation and cleanliness distribution of a conventional stationary rasp-bar sorghum thresher. Agricultural Engineering International: the CIGR E Journal Manuscript PM. 7 (28). Vol. 10. August.

Tabatabaeefar, A., H. Aghagoolzadeh and H. Mobli. (2003). Design and development of an auxiliary chickpea second sieving and grading machine. Agricultural Engineering International: the CIGR Journal of Scientific Research and Development. Manuscript FP. 3 (5). Vol. V. December.

Unal, H. (2009). Some Physical and Nutritional Properties of Hulled Wheat. Tarim Bilimleri Dergisi. Vol. 15 (1), pp: 58-64.

Unal, H., G. Izli, N. Izli and B. Asik. (2017). Comparison of some physical and chemical characteristics of buckwheat (Fagopyrum esculentum Moench) grains. CYTA Journal of Food. Vol. 15(2), pp: 257-265. 


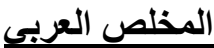

\section{تطوير نموذج أولى لتحسين أداء وحدة التظيف بألة الحصاد الجامعة}

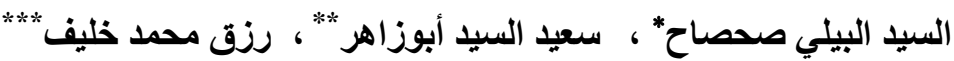

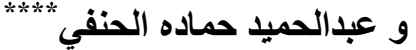

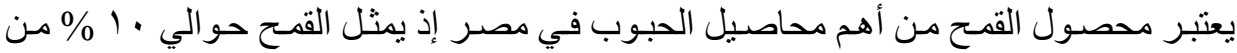
إجمالي الإنتاج الزراعي وحو الي • ب \% من إجمالي الواردات الزر اعيـة. كمـا تعد مصر أكبر

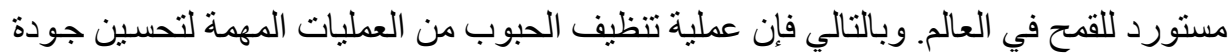
محصول القمح. تهدف الدر اسة إلى تطوير وحدة التنظيف داخل آلة الدر اس الجامعة (الكومباين) وذللك بتصنيع نموذج معملي لمحاكاة ودر اسة الخصائص الديناميكية للهو اء وتغيير أتجاه الهو اء بسحب الهو اء الى الخارج دون دفعه كما هو معلوم. كما تهدف ايضا الى الحد من التلوث بتجميع

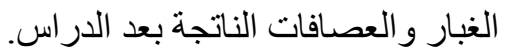

وقد أجريت التجارب المعملية الخاصة بالخو اص الطبيعية و الميكانيكية على حبوب القمح بمعل

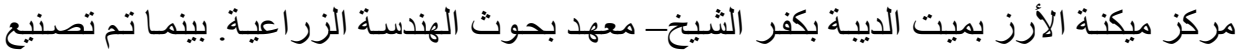
الوحدة و اختبار ها وتقييمها و التجارب المعملية لعملية التنظيف وفصل حبوب القهـ من الثـوائب بمعمل قسم الهندسة الزر اعيةـ كلية الزر اعة ـ جامعة كفر الثيخ.

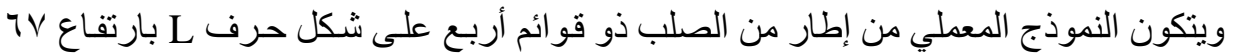

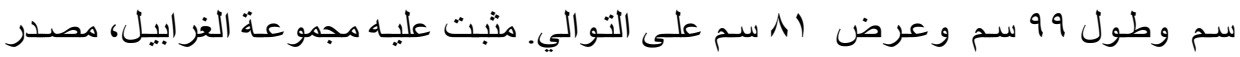

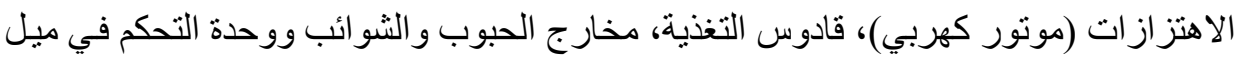
الغر ابيل .وحدة الغربلة تتكون من غربالين (علوي وسفلي) ولوح صلب بعرض • V سم وطول

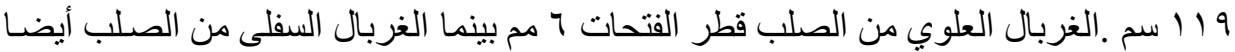

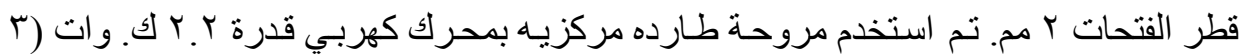

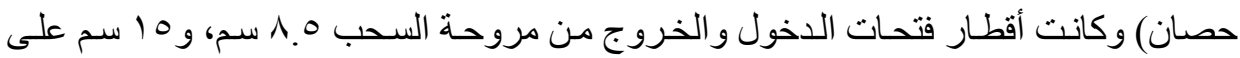

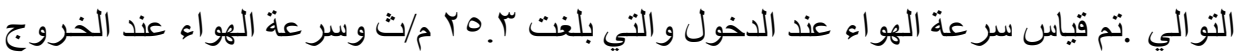

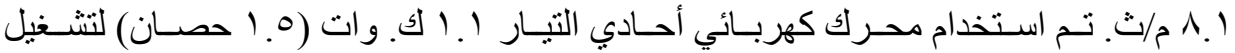

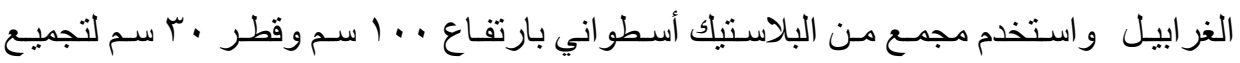

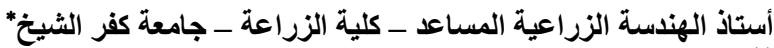

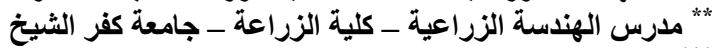

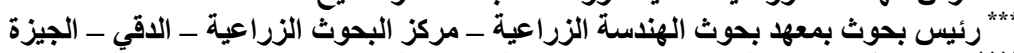

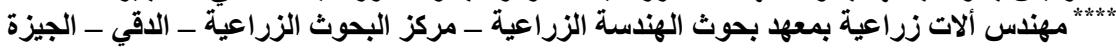


الشو ائب الخارجة من مروحة الطرد وذللك للحد من التلوث وتجميع التبن. ولقد تم تقييم النموذج

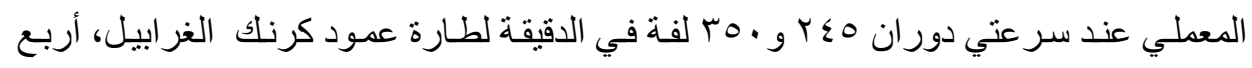

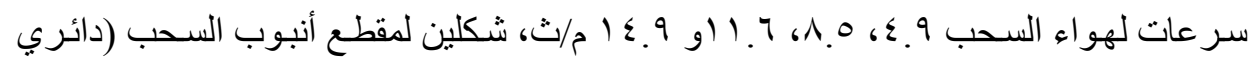

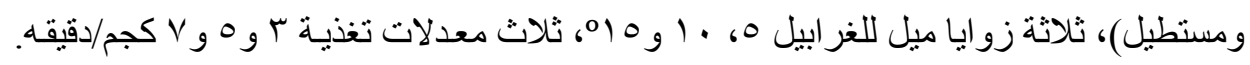

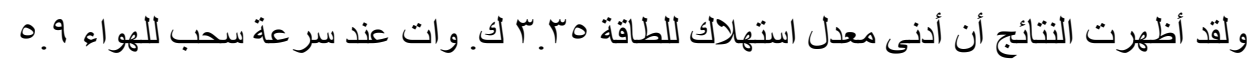

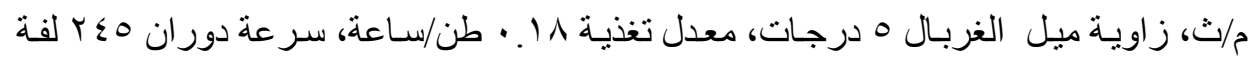

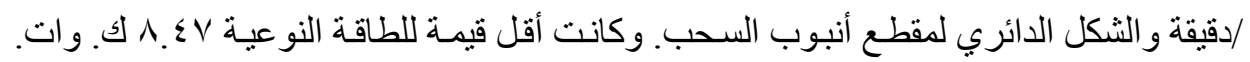

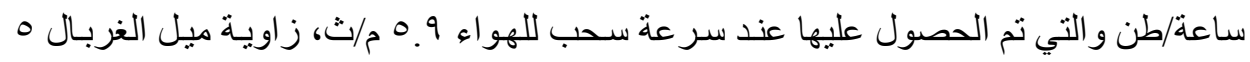

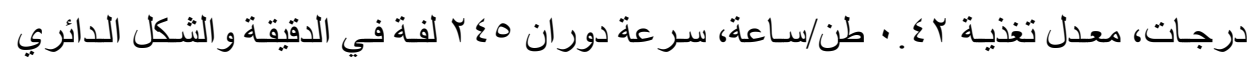

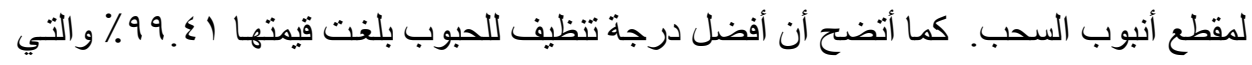

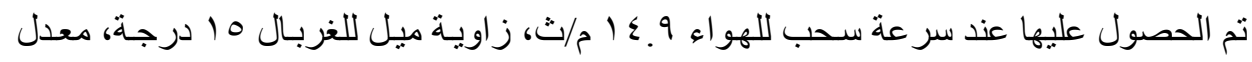
تغذية سكجم/دقيقه، سر عة دوران

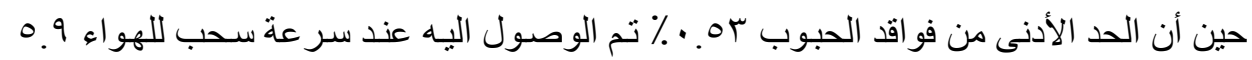
م/ت، زاوية مبل للغربـال 0 درجات، معدل تغذيـة سكجم/دقيقه، سر عة دوران

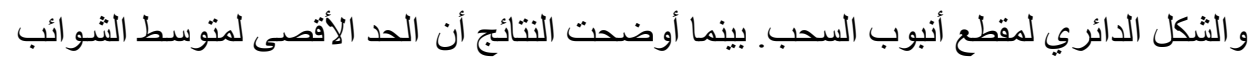

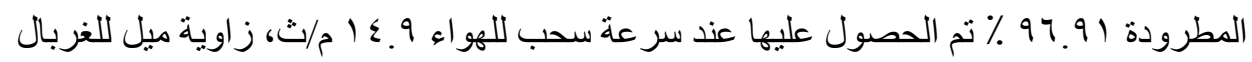

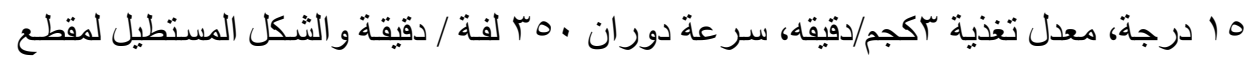
أنبوب السحب. 